Meanwhile, nobody can do much more than guess at what will happen, though it seems certain that something is bound to change the direction in which Man is going in 'breeding to high heaven' and using up apace the often irreplaceable resources of our planet. For it is a simple scientific fact that one cannot go on growing indefinitely, let alone exponentially, on the periphery of a finite globe, such as is constituted by the biosphere; sooner or later, something is bound to give way, and the longer this breaking-point is delayed, the greater is the ultimate fall likely to be.

But what of universal environmental awareness, which we started off so hopefully by contemplating? At its highest level of ethical appreciation and concomitant action, it could surely be the basis of biospheral survival and indeed global salvation-provided human population is kept within bounds. It is now clear that Man has the knowledge and capability to save the world, basically from himself through action to counter environmental constraints; it is not so clear that he will take the necessary action in time, being the profligate and avaricious creature he is, though we believe that he can be brought to do so through exercising his unique intelligence.

\title{
Of Ancient Parks and Trees
}

A s trees have always provided a leading feature of our environment very widely on Earth, any serious threats to them must cause grave concern. The devastation that has been wrought by a 'new' and virulent strain of the Dutch Elm Disease (caused by the Fungus Ceratocystis [Ceratostomella] ulmi) on the elms of both New and Old England, and more extensively on the North American and European continents, has again brought home to us forcibly the need to conserve our remaining parklands and especially the older trees that are commonly their most memorably attractive feature. Ulmus americana in North America, U. procera in England, and other species on the continent of Europe, are the ones mainly attacked by the disease. As they constitute leading features of the landscapes over wide areas, yet are being substantially exterminated throughout considerable portions of these areas, the environments of which they formed an outstanding feature are also changing considerably.

With these changes, much is lost-even beyond the pecuniary and amenity values of the trees themselves. A great deal of the charm of the villages of New England and elsewhere in North America is due to their long avenues of American Elms, with their graceful limbs reaching towards the heavens, while on the European side of the Atlantic, especially in England, we have the stately feathered Elms that gave so much of their charm to the famous playing fields of Eton, the University Parks and Christ Church Meadows at Oxford, the Backs and Trinity Fellows' Garden at Cambridge, Hyde Park in London, and numerous other situations. Apart from some places that are too remote for the weakly-flying vector beetle to have reached, and instances of (temporary?) saving by repeated costly injections, the English Elms have latterly been widely killed and removed or threatened, though many remain in a partly defoliated state or still stand as stark skeletal reminders of their former glory. Even the most judicious and costly planting of other trees, and hopes of survival through suckers in hedgerows, will not remedy these losses for several decades to come-if indeed ever.

Some of us well remember scares of such a situation already a few decades ago, when 'stag-headed' trees were to be seen which nevertheless commonly survived and even recovered from their lower parts. The strain of Ceratocystis that is currently attacking elms so widely is, however, commonly lethal-hence the present unfortunate situation.

These sad losses due to Nature should surely instil in us the resolve to preserve, far more actively than hitherto, the remaining 'feature' trees and aggregates from the depredations of Man. The several-thousand-years-old Bristlecone Pines (Pinus aristata) of Colorado, the Coast Redwoods (Sequoia sempervirens) and Giant Sequoias or Big Trees (Sequoiadendron giganteum) of the Pacific regions of the United States, the Beeches (Fagus sylvatica) of Burnham Beeches and Wittenham Clumps in southern England, and many other memorably outstanding dendrological 'monuments' of other types and places, should be treated as world or at least regional heritages, and preserved for all time to the extent that Nature allows.

But what of the ancient parkland and other areas in which such heritages grow, and of other landscapes which trees so widely embellish? It is a now-familiar truism that to conserve a plant population it is necessary to preserve its habitatincluding suitable conditions for its reproduction and, commonly, much of the ecosystem to which it belongs. Park ecosystems are anthropogenic, largely created and maintained by Man, and their conservation can be important for other reasons besides support of 'feature' trees. So let us maintain all we can of those that remain, with their fine old trees, often historical associations, and memorable picturesqueness. Far too many have already disappeared before the flood of 'progress' or been devastated in the interests of 'development'. With modern equipment it is all-too-easy to remove, practically 'at a stroke', a stately tree that may have taken centuries to grow-and stately trees, if healthy, are apt to occupy the best situations and yield the most valuable timber.

Many of us have pet trees that have been favourites from our youth-be they ancient oaks, towering elms, or gnarled apples. They are apt to stand out vividly in our childhood memories and to be recorded in our early photographs. Often they form major features in parks-particularly the older parks - and are important to retain. Sooner or later they will decline and die-to be replaced in well-managed instances by younger trees that have been interplanted towards this end. But to guard against such sweeping devastations as those of the old-and new-world elms mentioned above, or of the Blight (Endothia parasitica) which struck the Sweet Chestnut (Castanea dentata) of eastern North America fairly early in this century, the plantings should be of a judicious mixture of species rather than of a single species-however hardy and secure this may seem at the time.

So may we think 'of ancient parks and trees', and must do our best to preserve all the worthy examples of them that we can-throughout the world. And where new parks can be created, the lessons of the Dutch Elm Disease and Chestnut Blight should be remembered-at least to the extent of planting appropriate mixtures and avoiding monocultures. Above all it must be remembered that trees have provided a leading feature of Man's environment since early in his evolution, and must surely so continue.

N. P. 